\title{
Piotr Kołakowski
}

Słupsk

\section{Współpraca polskiego wywiadu wojskowego z Secret Intelligence Service w drugiej połowie lat trzydziestych XX w.}

Abstrakt: Oddział II SGWP przywiązywał dużą wagę do współpracy informacyjnej z Brytyjczykami, jednak dopiero w drugiej połowie lat trzydziestych kontakty na płaszczyźnie wywiadowczej stały się bardziej efektywne. Dotyczyły one zarówno rozpoznania potencjału militarnego ZSRS, jak i Niemiec hitlerowskich. Prawdziwy przełom we współpracy nastąpił w kwietniu 1939 r., po udzieleniu sobie przez Zjednoczone Królestwo i Polskę gwarancji bezpieczeństwa na wypadek agresji III Rzeszy.

Słowa kluczowe: polski wywiad wojskowy, Secret Intelligence Service, polsko-brytyjska współpraca wywiadowcza, III Rzesza, Związek Sowiecki.

Abstract: The Second Department of the Polish General Staff attached great importance to the cooperation with the British, but it was not until the second half of the 1930s that contacts became more effective. They covered the military potential both of the USSR and Nazi Germany. A true breakthrough in the cooperation took place in April 1939, after the United Kingdom and Poland formalised their mutual military assistance in the event of aggression of the Third Reich.

Keyw ords: Polish military intelligence, Secret Intelligence Service, Polish-British intelligence cooperation, Third Reich, Soviet Union.

Dla polskiego wywiadu wojskowego istotne znaczenie, zwłaszcza u progu II wojny światowej, miała współpraca ze służbami informacyjnymi Wielkiej Brytanii będacej - podobnie jak sojusznicza Francja - gwarantem ładu wersalskiego, jaki został ukształtowany po zakończeniu I wojny światowej. Nie 
była ona jednak tak owocna, jak z wywiadem francuskim, z którym cyklicznie organizowano konferencje ewidencyjne. Wpływ na ograniczone kontakty wywiadowcze miał przede wszystkim stan stosunków polityczno-wojskowych. W polityce Londynu państwo polskie zajmowało dość odległe miejsce, co wynikało z braku większego nim zainteresowania zarówno pod względem politycznym, gospodarczym, jak i strategicznym. Brytyjska polityka zagraniczna - pomimo iż sprawy europejskie odgrywały istotna rolę - miała w okresie dwudziestolecia międzywojennego charakter globalny. Polska leżała de facto poza strefa bezpośredniego zainteresowania Brytyjczyków. Stosunek do niej był pochodna polityki Zjednoczonego Królestwa wobec Związku Sowieckiego i Niemiec ${ }^{1}$. Niechęć nad Tamizą wzbudzał zapewne sojusz polsko-francuski z powodu obaw Londynu przed supremacja Paryża w Europie.

Do pierwszych polsko-brytyjskich kontaktów wywiadowczych doszło już w czasie wojny II Rzeczypospolitej z Rosją bolszewicka. Przy rezydującej w Polsce brytyjskiej misji wojskowej funkcjonowała komórka Secret Intelligence Service, co jednak nie zaowocowało nawiazaniem ściślejszej współpracy między obiema służbami. W kolejnych latach kontakty były systematycznie rozszerzane i obejmowały z jednej strony problematykę wojskowa, a z drugiej - polityczną ${ }^{2}$. Wymiana informacji odbywała się przede wszystkim w odniesieniu do Związu Sowieckiego, w którym obie strony dostrzegały śmiertelne zagrożenie. Nie bez znaczenia były również źle układające się relacje, w tym „zatarg między Anglią i Rosją Sowiecką". Według wytycznych z marca 1928 r., opracowanych przez polski Oddział II do rozmów w War Office w sprawie współpracy wywiadowczej, należało w pierwszej kolejności wyjaśnić, czy „obecne ustosunkowanie się angielskiego Sztabu do nas” wypływa z chęci „szczerej współpracy droga wymiany informacji jako z organem poważnym”, czy też Brytyjczycy dążyli do potraktowania polskiej „dwójki” jako jednego ze „swoich źródeł wywiadu” i - jak to określono - eksploatacji rezultatów jej pracy.

Oddziałowi II zależało na otrzymywaniu „w niektórych specjalnie nas obchodzących działach wiadomości o Rosji Sowieckiej, droga wspólnego stwierdzenia stanu faktycznego i ustalenia rzeczy watpliwych i wymagajacych dalszych poszukiwań”3. Była to zasada - co podkreślano - stosowana przez

\footnotetext{
${ }^{1}$ Zob. M. Nowak-Kiełbikowa, Polska - Wielka Brytania $w$ dobie zabiegów o zbiorowe bezpieczeństwo $w$ Europie 1923-1937, Warszawa 1989; M. Nurek, Polska w polityce Wielkiej Brytanii w latach 1936-1941, Warszawa 1983, s. 316-317; M.J. Zacharias, Polityka Wielkiej Brytanii w przededniu drugiej wojny światowej, w: Droga ku wojnie. Polityka europejska i amerykańska w przededniu drugiej wojny światowej, red. T. Kisielewski, Bydgoszcz 1999, s. 85 i n.

2 A. Pepłoński, Wywiad polski na ZSRR 1921-1939, Warszawa 1996, s. 207-208.

${ }^{3}$ Archiwum Akt Nowych (dalej: AAN), Attachés wojskowi RP przy rządach państw kapitalistycznych 1919-1939 (dalej: Attachaty wojskowe), AII/118, Projekt rozmów w War Office z 22 II 1928 r.
} 
polski wywiad wojskowy wobec „wszystkich Sztabów Generalnych” przez organizowanie wspólnych konferencji ewidencyjnych. Program rozmów, wysunięty ze strony polskiej, dotyczył następujacych spraw: 1) ustalenie O de B oraz dyslokacji pokojowej wojsk lądowych i marynarki wojennej Sowietów (specjalny nacisk miał być położony na lotnictwo i artylerię); 2) określenie stanu liczebnego Armii Czerwonej w czasie pokoju; 3) rozpoznanie produkcji zbrojnej, a także zasobów materialnych sowieckiej armii. Ciekawe, iż proponowano nie poruszać w rozmowach z przedstawicielami wywiadu brytyjskiego kwestii syntetycznie naświetlających wartość bojową RKKA oraz jej możliwości mobilizacyjnych i zamiarów wojennych ${ }^{4}$.

Propozycje strony polskiej dotyczące rozmów ewidencyjnych nie spotkały się ze zrozumieniem Brytyjczyków, którzy oświadczyli, iż nie widzą potrzeby zorganizowania takiego spotkania. Sugestie w sprawie przyjazdu oficera określono wręcz jako „dość kosztowny sposób wymiany myśli” (!). Attaché wojskowy w Londynie, mjr Roman Michałowski informował Oddział II, że „War Office okazuje dużą ostrożność pod presją Foreign Office, które właśnie obecnie chce uniknąć wszelkich pozorów zbliżania się do niektórych państw z zewnętrznymi pozorami tworzenia bloków przeciw trzecim państwom"5. Do końca 1928 r. sygnalizował on niewielkie zainteresowanie brytyjskich służb wywiadowczych kooperacją z polska „dwójką" ${ }^{\text {. }}$

${ }^{4}$ Ibidem.

${ }^{5}$ Cyt. za: H. Ćwięk, W tajnej stużbie II Rzeczypospolitej. Wywiad polski wobec Niemiec 1918-1939, Częstochowa 2009, s. 311.

${ }^{6}$ W tym miejscu chciałbym się odnieść do kolejnych insynuacji Łukasza Ulatowskiego. Po dziesięciu miesiącach od ukazania się mojego listu w „Dziejach Najnowszych” (2016, nr 1), odpowiadając w skandaliczny sposób na recenzję prof. A. Pepłońskiego w „Przeglądzie Historyczno-Wojskowym” (2016, nr 2-3), Ulatowski postanowił użyć wobec mnie najcięższej broni, stawiając zarzut - jak to ują - „filiacji jego ustaleń”. Zarzut ten jest absurdalny nie tylko ze względu na charakter zamieszczonej przeze mnie publikacji w „Newsweeku”, ale przede wszystkim z powodu użytych argumentów. W artykule podałem, że „na czele [wywiadu KOP - P.K.] stał od 1937 r. mjr Jan Gurbski (początkowo jako pełniący obowiązki szefa, a od 24 października 1938 r. - szef)". To nie Ulatowski - jak próbuje sobie przypisać - wprowadził datę objęcia Szefostwa Wywiadu KOP przez mjr. Gurbskiego do obiegu naukowego, bowiem informacja o powołaniu Gurbskiego na szefa wywiadu KOP w tym okresie funkcjonuje w nauce od ponad dekady (zob. np.: Wrzesień 1939 r. Radzieckie zagrożenie Rzeczypospolitej $w$ dokumentach, relacjach $i$ wspomnieniach, wybór i oprac. W. Włodarkiewicz, Warszawa 2005, s. 187). O nieznajomości przez Ulatowskiego podstawowej literatury tematu świadczy także zarzut dotyczący rzekomego „zapożyczenia” przeze mnie numerów placówek wywiadowczych KOP - znane są one przynajmniej od 2004 r. Ulatowski stwierdził również, iż z jego książki zaczerpnąłem informację, że sieć placówek na terenie sowieckim obejmowała na przełomie czerwca i lipca 1939 r. 14 oficerów: „Kołakowski napisał: «w lipcu 1939 r. działało 14 placówek [...] w Związku Sowieckim»”. To kolejna manipulacja, bowiem w tekście stwierdziłem: „W lipcu 1939 r. działało 14 placówek obserwacyjno-informacyjnych w Związku Sowieckim. Oprócz nich funkcjonowało 12 placówek limitrofowych (łączności, informacyjnych i mobilizacyjnych)". Wykorzystałem tu nie ustalenia Ulatowskiego, lecz odpis dokumentu, jaki odnalazłem w archiwum w Moskwie. Ulatowski - co chcę podkreślić 
Trzeba zauważyć, iż pomimo poszukiwania możliwości zacieśnienia więzi ze służbami informacyjnymi Zjednoczonego Królestwa również w warszawskiej centrali wywiadu wojskowego z dystansem podchodzono do możliwości wzajemnej współpracy wywiadowczej. Przede wszystkim dostrzegano przejawy nielojalności Brytyjczyków w kontaktach z „dwójką, a także ich aktywna działalność szpiegowską na terytorium II Rzeczypospolitej i w Wolnym Mieście Gdańsku. Ponadto materiał informacyjny przekazywany przez nich wzbudzał

- nie wymienił w swojej książce wszystkich 12 placówek limitrofowych. Świadczy to, iż wiadomość pochodzi z moich źródeł moskiewskich, w przeciwnym razie Ulatowski podałby je zapewne w swojej pracy. W „Dziejach Najnowszych” na temat 14 placówek funkcjonujących w ZSRS napisałem: „Łukasz Ulatowski błędnie identyfikuje sieć placówek Referatu «Wschód» w ZSRS działających na przełomie czerwca i lipca 1939 r., gdyż w lipcu tego roku nie funkcjonowały tam placówki «N.38» i «P.1», za to istniały pominięte przez niego «W.6», «T.8», «S.2», «Brandt», «R.3» i «K.10»”. Niestety, Ulatowski sprytnie przemilcza ten fakt. Tak więc ,jego" placówki z przełomu czerwca i lipca to nie te same, które podałem, choć liczba 14 placówek się zgadza (!). Ulatowski wykazuje też poważne braki w umiejętności czytania ze zrozumieniem. Odnośnie do placówki „Rex” stwierdziłem jedynie: „nie jest prawda, że [jak uważa Ulatowski - P.K.] placówka «Rex» występuje tylko w materiałach "wojskowej bezpieki» po 1945 r." - nazwa ta pojawia się również w sprawozdaniach informacyjnych Oddziału II SGWP z 1939 r. Nie rozumiem zatem, skąd w jego replice tak zapalczywy wywód na ten temat? Na koniec Ulatowski skonkludował: „Jedynie brak miejsca uniemożliwia mi wskazanie kolejnych filiacji pomiędzy moimi tekstami a Kołakowskiego. Podkreślić należy, że «Czas próby» [moja książka - P.K.] był tzw. książką profesorską napisaną przed złożeniem wniosku w Centralnej Komisji do spraw Stopni i Tytułów Naukowych w zwiazku ze wszczęciem procedury nadania tytułu profesora zwyczajnego przez prezydenta RP". Pomijam już fakt niewiedzy, iż to nie prezydent „nadaje tytuł profesora zwyczajnego" - co jest kolejnym przykładem ignorancji, braku szerszej wiedzy (z tą podstawową również u niego nie najlepiej, o czym świadczy reforma kalendarza gregoriańskiego, jakiej dokonał w swojej książce o polskim wywiadzie wojskowym w 1939 r., stwierdzając na s. 77, że miesiąc kwiecień ma 31 dni). Ulatowski świadomie rozmija się z prawdą gdyż doskonale wie, że moja książka w rzeczywistości ukazała się pod koniec 2011 r. (choć wydawnictwo podało rok 2012 - co jest praktykowane), a jego praca przynajmniej półtora roku później, bo w 2013 r. Również inne teksty tego autora (aspirujące do miana naukowych, lecz pozbawione aparatu badawczego) są późniejsze od mojej książki. W takim razie, jak mogłem zapożyczać informacje? Pisząc o filiacji jego tekstów, Ulatowski pragnie zwrócić na siebie uwagę i podnieść rangę swych dokonań. To metoda dość prymitywna i niemająca nic wspólnego z dyskusją naukową. Dziwić może również nader zaskakująca zbieżność: gdy piszę o Oddziale II w 1939 r., po jakimś czasie Ulatowski również publikuje na ten temat, kiedy pojawia się moja książka o mjr. Sosnowskim - sytuacja powtarza się. Poziom wiedzy Ulatowskiego o polskim wywiadzie wojskowym nie pozostawia złudzeń. Świadczy o tym chociażby mizerna znajomość pracy placówek wywiadowczych: o jednych (o czym napisałem już w „Dziejach Najnowszych”) „zapomina”, a w przypadku innych - błędnie podaje czas powstania i przedłuża ich działalność. Nie zna też nawet prawidłowej nazwy polskiego wywiadu wojskowego w czasie II wojny światowej, bowiem posługuje się dla lat 1939-1945 nazwą Oddział II Sztabu Naczelnego Wodza, a tymczasem od 1942 r. obowiązywała nazwa Oddział Informacyjno-Wywiadowczy Sztabu Naczelnego Wodza (zob. np.: Polski wywiad wojskowy w 1939 roku. Struktura organizacyjna, sktady osobowe, personel, budżet, mob., Warszawa 2013, s. 207), a to już kompromitacja. 
wiele wątpliwości, bowiem zawierał nieścisłości ${ }^{7}$. Jak zatem w praktyce wyglądały w latach trzydziestych kontakty Oddziału II Sztabu Głównego WP z Secret Intelligence Service (SIS - Tajna Służba Wywiadowcza)?

3 IX 1934 r. w Grosvenor Hotel w Londynie odbyła się konferencja pomiędzy przedstawicielami wywiadów obu państw. Gospodarzy reprezentowali: płk Stewart Menzies - zastępca szefa SIS, mjr John P. Shelley - szef centrali wywiadowczej na Bliski Wschód w Jerozolimie i mjr R.H. Plowden. Ze strony polskiej w rozmowach uczestniczyło dwóch oficerów. Był to por. Jerzy Niezbrzycki - kierownik Referatu „Wschód” Wydziału II Wywiadowczego i mjr Stanisław Orłowski ps. „Oscar Sander”, który miał objać placówkę w Persji, utworzona w porozumieniu z wywiadem brytyjskim ${ }^{8}$. Praktycznie cała konferencję zdominowały kwestie związane z jej uruchomieniem. Zadaniem Oscara Sandera było zorganizowanie działalności wywiadowczej na terenie Persji i Afganistanu, skierowanej na Związek Sowiecki. Miał on jednak prowadzić prace o charakterze mobilizacyjnym na wypadek wojny. Działalność pokojowa planowano ograniczyć do nadzwyczajnych wypadków. SIS miała zapewnić placówce wywiadowczej łączność z centralą. Brytyjczycy byliby zobowiązani także do współpracy w zakresie kontrwywiadowczym oraz udzielania wsparcia w sprawach technicznych, jak np. załatwiania wiz czy też dostarczania informacji na temat stosunków panujących na Bliskim Wschodzie. Menzies zaproponował, aby mjr Orłowski pracował pod maska „kupca z niewielkim kapitałem własnym". Przy okazji, podczas kolacji w Travellers Club, por. Niezbrzycki omówił z nim oraz z płk. Fletcherem (szefem Wydziału Organizacyjno-Analitycznego) aktualne możliwości pracy wywiadowczej na ZSRS, ze szczególnym uwzględnieniem jego europejskiej części ${ }^{9}$.

Należy podkreślić, iż kierownik Referatu „Wschód” przywiązywał do pracy placówki „Radames” duże znaczenie, co było podyktowane jej charakterem mobilizacyjnym. Jednak znikoma pomoc, jaka mjr. Orłowskiemu udzielili ostatecznie Brytyjczycy, świadczyła o niechęci do rozwijania działalności wywiadowczej przez polski wywiad wojskowy na kontrolowanym przez nich Bliskim Wschodzie. O niepowodzeniu misji Oscara Sandera zdecydowały nie tylko trudności stworzone przez SIS, ale i miejscowe warunki. Niewatpliwie także mjr Orłowski popełnił błędy, które negatywnie odbiły się na niektórych przedsięwzięciach. Strona brytyjska, co trzeba przyznać, podczas wrześniowej

\footnotetext{
${ }^{7}$ A. Pepłoński, op. cit., s. 208-210.

${ }^{8}$ Centralne Archiwum Wojskowe (dalej: CAW), Oddział II Sztabu Głównego/ Generalnego Wojska Polskiego (dalej: Oddział II SGWP), I.303.4.2068, Protokół konferencji pomiędzy przedstawicielami Oddziału II Sztabu Głównego WP oraz przedstawicielami Secret Service Armii Angielskiej odbytej w dniu 3 IX 1934 r. w Londynie.

${ }_{9}$ Pułkownik Menzies w rozmowie z por. Niezbrzyckim stwierdził, iż SIS interesowały w odniesieniu do ZSRS dwa zasadnicze problemy. Było to studium zagadnień polityki wewnętrznej i możliwości mobilizacyjne przemysłu. Kierownik Referatu „Wschód” przyrzekł, że Oddział II zrobi wszystko, by „umożliwić ich aparatowi podejście do tych kwestii”. Ibidem.
} 
konferencji ostrzegała por. Niezbrzyckiego, „że w związku z proponowana praca p. Sandera na terenie Persji ułatwienia tej pracy ze strony angielskiej moga być b. ograniczone, pomimo całej dobrej woli z ich strony, ze względu na ogólne trudności terenowe oraz trudności w których obecnie Secret Service na tym terenie się znajduje"10. Bez większego przekonania do tego przedsięwzięcia odnosiło się zresztą od początku kierownictwo Oddziału II Sztabu Głównego WP.

Zakres współpracy pomiędzy służbami wywiadowczymi obu państw podał kpt. Jerzy Niezbrzycki, który podczas spotkania z oficerami polskiego wywiadu w kwietniu 1936 r. powiedział, że nie ma żadnej współpracy organizacyjnej między Oddziałem II a wywiadem brytyjskim. Kontakty ze służbami informacyjnymi Wielkiej Brytanii określił jako przypadkowe.

W drugiej połowie lat trzydziestych polsko-brytyjska współpraca wywiadowcza stała się jednak bardziej aktywna zarówno w odniesieniu do Niemiec hitlerowskich, jak i Związku Sowieckiego. Efekty zaczęło przynosić porozumienie zawarte między przedstawicielami SIS a Oddziałem II Sztabu Głównego WP. Placówka wywiadu brytyjskiego w Warszawie nawiązała bezpośredni kontakt z Referatem „Zachód” Wydziału II Wywiadowczego. Grunt pod tę współpracę przygotował kpt. Niezbrzycki, kierujący w dalszym ciagu wywiadem strategicznym na Związek Sowiecki' ${ }^{11}$. Od 17 IX do 26 X 1937 r. odbyło się kilka spotkań i konferencji oficerów polskiej „dwójki” z mjr. Johnem P. Shelleyem, który stał na czele placówki wywiadowczej w stolicy Polski. 15 października przekazał on materiał wywiadowczy Referatowi „Zachód”. Sześć dni później kierownik Referatu „Wschód” kpt. Niezbrzycki skierował list do płk. Menziesa w sprawie zacieśnienia współpracy ${ }^{12}$. Przypomnijmy, iż mjr/ppłk Shelley był dobrze znany oficerom polskiego wywiadu wojskowego z wcześniejszych kontaktów. Oficjalnie kierował on w latach 1936-1939 biurem paszportowym brytyjskiej placówki dyplomatycznej w Warszawie. Zagraniczne ekspozytury SIS (Stations - stacje) działały pod przykrywka tzw. Oficerów Kontroli Paszportowej (Passport Control Officers). Umożliwiało to Tajnej Służbie Wywiadowczej prowadzenie działalności we wszystkich krajach, z którymi Londyn utrzymywał stosunki dyplomatyczne ${ }^{13}$. Major

${ }^{10}$ Ibidem. Zakładano, iż placówką „Ramades” mjr Orłowski będzie kierował ok. 5 lat. Tymczasem przebywał on na Bliskim Wschodzie od grudnia 1934 r. (23 tego miesiąca przyjechał do Bagdadu) do września 1935 r., kiedy stamtąd wyjechał do Aten. W Iraku był ponad 5 miesięcy, w Persji - ok. 3, Syrii oraz Palestynie - 1 miesiąc, a w różnych krajach europejskich - 2 miesiace. Do Warszawy Oscar Sander przyjechał 20 X 1935 r.

11 Według ustaleń Pepłońskiego kontakt z Referatem „Zachód” nawiązał kpt. H. Hamilton-Stokes, kierujący warszawską placówką SIS do połowy 1936 r. Jego następcą mianowano mjr. Shelleya. A. Pepłoński, op. cit., s. 213.

12 Rossijskij Gosudarstwiennyj Wojennyj Archiw w Moskwie, 2-j Otdieł Gienieralnogo Sztaba Polszi (g. Warszawa), fond 308k, op. 2, d. 31, „Gin” 1938, 1. 1.

${ }^{13}$ J. Ciechanowski, Brytyjskie stużby specjalne, w: Polsko-brytyjska wspótpraca wywiadowcza podczas II wojny światowej, t. I: Ustalenia Polsko-Brytyjskiej Komisji Historycznej, red. T. Dubicki, D. Nałęcz, T. Stirling, Warszawa 2004, s. 147. 
Szumowski, który od marca do sierpnia 1939 r. pełnił funkcję kierownika Referatu „Zachód” i miał kontakt osobisty z Shelleyem, tak go scharakteryzował: „wzrost około $1.75 \mathrm{~m}$, lat około 50, ryżawy blondyn z małym wasikikiem robił wrażenie bardzo spokojnego i opanowanego człowieka"14. (Powszechnie znaną tajemnicą było, iż ppłk Shelley miał poważne kłopoty ze swoją młoda polska żoną obdarzoną znacznym temperamentem). Pełnił on rolę oficera łącznikowego zarówno przy Referacie „Wschód”, jak i Referacie „Zachód”. Rzecz ciekawa, iż w kontaktach z Oddziałem II pozostawali też eksponenci wywiadu brytyjskiego w Pradze i Rydze.

Nie ulega wątpliwości, iż Oddział II Sztabu Głównego WP w ramach kontaktów wywiadowczych z wywiadem brytyjskim dostarczył wielu ważnych wiadomości. Brytyjczycy - o czym należy wspomnieć - m.in. za pośrednictwem swojego ataszatu wojskowego w Warszawie regularnie zwracali się o opinie i konsultacje do centrali polskiej „dwójki”. Udzielane przez wywiad polski informacje $\mathrm{z}$ odcinka zachodniego były traktowane jako rekompensata za pomoc brytyjska na odcinku wschodnim.

W pierwszej połowie grudnia 1937 r. Brytyjczycy zabiegali o wiadomości pozwalające naświetlić liczebność Wehrmachtu z podziałem na Heer, Luftwaffe i Kriegsmarine. Oprócz tego zainteresowani byli fotografiami oraz danymi technicznymi najnowszego sprzętu bojowego. Chodziło przede wszystkim o czołgi i działa. Wywiad brytyjski zwracał się również o informacje na temat dywizji tworzących XIV i XV Korpus, organizacji wojennej korpusów, formowania nowych jednostek pancernych, organizacji i wyposażenia dywizji szybkich, a także zapasów mobilizacyjnych formacji czynnych. Poproszono także Oddział II o dane, jakie były w jego dyspozycji, na temat żołnierzy zwolnionych do rezerwy we wrześniu i październiku tego roku po odbyciu dwuletniej służby ${ }^{15}$. Nie wiadomo, czy chodziło o weryfikację własnych informacji, czy też SIS nie posiadało żadnych wiadomości na ten temat.

Oczywiste było, iż wywiad Zjednoczonego Królestwa rewanżował się stronie polskiej doniesieniami własnego aparatu informacyjnego. W maju $1937 \mathrm{r}$. otrzymano z tego źródła cenne wiadomości na temat produkcji samolotów w Niemczech. Na podstawie danych SIS ich miesięczna produkcja wynosiła 360 sztuk. Informacje te, co ważne, nie odbiegały od obliczeń francuskich i stanowiły cenne uzupełnienie „skapych własnych wiadomości” Oddziału II Sztabu Głównego WP na ten temat ${ }^{16}$.

${ }^{14}$ Wojskowe Biuro Badań Historycznych (dalej: WBBH), Materiały i Dokumenty (dalej: MiD), I/3/94, Sprawozdanie mjr dypl. Tadeusza Szumowskiego szefa Samodzielnego Referatu Zachód Oddziału II (wywiadu głębokiego, czyli strategicznego na Niemcy) za czas 19 III 1939 r. do 27 VIII 1939 r., s. 11.

${ }^{15}$ CAW, Oddział II SGWP, I.303.4.3715, Pytania wywiadu brytyjskiego do Oddziału II z XI i XII $1937 \mathrm{r}$.

${ }^{16}$ Ibidem, I.303.4.2250, Sprawozdanie z konferencji ewidencyjnej odbytej w Paryżu z francuskim Oddziałem II Ministerstwa Lotnictwa w dniach 26 i 27 V 1937 r. 
Wiosną 1938 r., po aneksji Austrii, polski wywiad wojskowy zaczął zwracać większą uwagę na Czechosłowację, co było konsekwencją napięcia na linii Berlin-Praga. W ramach kontaktów wywiadowczych „dwójka” otrzymała od SIS szczegółowe O de B armii czechosłowackiej z obsadą personalną wszystkich ważniejszych stanowisk oraz większych jednostek ${ }^{17}$. W zamian Oddział II zrewanżował się cennymi informacjami dotyczącymi Związku Sowieckiego. W 1938 r. przekazano wiadomości na temat kadry dowódczej, organizacji, uzbrojenia i dyslokacji jednostek Armii Czerwonej, przemysłu zbrojeniowego, infrastruktury kolejowej i drogowej, a także sytuacji wewnętrznej w Związku Sowieckim. Wywiad brytyjski odnosił sie „z wielkim uznaniem” do informacji otrzymywanych od strony polskiej. Tak było np. z danymi dostarczanymi na początku kwietnia 1938 r., dotyczącymi formowania nowych jednostek zmotoryzowanych w Armii Czerwonej. Ich ocenę Brytyjczycy przedstawili „dwójce” na początku czerwca tego roku. Należy wspomnieć w tym miejscu, iż wiosną $1937 \mathrm{r}$. Londyn zwrócił się o informacje odnoszące się do „prawdziwych powodów” rozstrzelania kadry dowódczej Armii Czerwonej. SIS poszukiwał też wszelkich wiadomości na temat badań prowadzonych w ZSRS nad bronią bakteriologiczną i chemiczna.

W 1938 r. wymiana informacji pomiędzy służbami wywiadowczymi Polski i Zjednoczonego Królestwa dotykała też kwestii politycznych. Wśród nich znajdowały się zagadnienia dotyczace polityki Moskwy w razie konfliktu niemiecko-czechosłowackiego, relacji sowiecko-japońskich, stosunków ZSRS z Chinami oraz Litwa, a także - co miało ogromne znaczenie dla państwa polskiego - możliwości zbliżenia z III Rzesza. Niestety nie wiemy, jakie stanowisko w tej ostatniej sprawie przedstawił Oddział II, a jakie Brytyjczycy. Można tylko przypuszczać, iż wykluczano powrót Związku Sowieckiego i Niemiec do polityki współpracy.

Na początku maja 1938 r. wywiad brytyjski przekazał stronie polskiej informacje o armii niemieckiej. Według tych danych siły lądowe tworzyło 6 dowództw grup, 18 korpusów, 3 dywizje pancerne, 6 dywizji piechoty zmotoryzowanej $(2,6,10,13,20$ i 29$)$, co nie do końca odpowiadało prawdzie ${ }^{18}$, dywizja górska, dywizja lekka i brygada kawalerii, a także szereg oddziałów dyspozycyjnych. Była armia austriacka wzmocniła siły zbrojne III Rzeszy o dodatkowe 6 dywizji piechoty, dywizje piechoty zmotoryzowanej i 2 dywizje górskie. Prawidłowo wywiad brytyjski określił XVI Korpus jako pancerny, który miał swoje „przypuszczalne” miejsce postoju w Berlinie (co było zgodne z prawda). Właściwie zlokalizowano nowe dowództwa pozostałych korpusów: XIV w Magdeburgu, XVII w Wiedniu i XVIII w Salzburgu oraz błędnie XV w Köln (znajdowało się w Jenie) ${ }^{19}$.

${ }_{17}$ P. Kołakowski, Między Warszawa a Praga. Polsko-czechosłowackie stosunki wojskowo-polityczne 1918-1939, Warszawa 2007, s. 405.

${ }_{18}$ Błąd wywiadu brytyjskiego polegał na tym, iż 6 i 10 dywizje nie były zmotoryzowane.

${ }^{19}$ CAW, Oddział II SGWP, I.303.4.3715, Informacje o wojsku niemieckim otrzymane od wywiadu brytyjskiego z 4 V 1938 r. 
22 VI 1938 r. ppłk Shelley nadesłał do centrali polskiego wywiadu wojskowego dane na temat produkcji sprzętu bojowego w III Rzeszy ${ }^{20}$. W tym miesiącu Brytyjczycy zwrócili się z prośbą do Oddziału II o przekazanie informacji dotyczacych niemieckich sił powietrznych. Chodziło przede wszystkim o uzyskanie wiadomości odnośnie do rozbudowy lotnictwa, obrony przeciwlotniczej oraz szkół lotniczych. Strona brytyjska niejednokrotnie stwierdzała, „że informacje lotnicze z Niemiec posiadają wielkie znaczenie”. Również w czerwcu 1938 r. SIS poszukiwał danych technicznych bomb zapalających, sposobów prowadzenia przez Luftwaffe bombardowań czy też budowania schronów. W miarę możliwości Oddział II starał się jak najszybciej udzielać odpowiedzi na te pytania. Wiadomo, iż przekazano Brytyjczykom informacje o obronie przeciwlotniczej w Niemczech, w tym w Zagłębiu Ruhry. „Dwójka” dostarczyła też wiadomości o pracach nad napędem rakietowym, jakie były prowadzone w III Rzeszy. Już w marcu 1937 r. SIS kanałami wywiadowczymi zapytywał centralę polskiego wywiadu wojskowego o prawdziwość pogłosek, „że system napędu rakietowego jest wypróbowywany". Brytyjczyków, którzy niepokoili się tymi pracami, interesował aktualny stan badań. Pytano przede wszystkim o jego zastosowanie w produkcji masowej samolotów, torped i pocisków.

Trzeba wspomnieć, iż polski wywiad wojskowy w latach trzydziestych uzyskał na temat niemieckich prac nad bronia rakietową wiele interesujących informacji. Wśród nich były dane o urządzeniach i próbach z pociskami rakietowymi w specjalnym ośrodku w Peenemünde. Informacje o nim pochodziły od niezwykle cennego agenta „dwójki” Wiktora Katlewskiego, który pracował w Urzędzie Uzbrojenia Kriegsmarine. Niezależnie wiadomości na ten temat przesyłała placówka „Port” w Szczecinie, kierowana przez chor. Kazimierza Ziembiewicza. Część materiałów dotyczących broni rakietowej Oddział II przekazał w ramach współpracy wywiadowczej stronie brytyjskiej, co niewątpliwie miało ogromne znacznie, lecz nie zostało przez Londyn właściwie docenione ${ }^{21}$.

Z dokumentów polskiego wywiadu wojskowego wynika, iż pod koniec października 1938 r. wywiad brytyjski poszukiwał danych odnośnie do nowego uzbrojenia i wyposażenia armii niemieckiej. W tym czasie interesowano się przede wszystkim sprzętem artyleryjskim, a także „bronią znajdującą się w stadium doświadczalnym" ${ }^{22}$. Gwałtowny rozwój lotnictwa oraz jednostek

${ }^{20}$ Kierownik placówki wywiadu brytyjskiego w Warszawie przekazał wówczas również informacje na temat Związku Sowieckiego. Dotyczyły one m.in. sił morskich tego państwa.

${ }^{21}$ A. Woźny, Niemieckie przygotowania do wojny z Polska $w$ ocenach polskich naczelnych władz wojskowych w latach 1933-1939, Warszawa 2000, s. 106-107. Leszek Gondek o informacjach przekazanych Oddziałowi II przez Katlewskiego napisał: „Nabiera to szczególnej wymowy w kontekście późniejszych usilnych starań aliantów o zgłębienie tajemnic wspomnianego ośrodka”. Idem, Wywiad polski w III Rzeszy 1933-1939. Zarys struktury, taktyki i efektów obronnego działania, Warszawa 1982, s. 313.

${ }^{22}$ CAW, Oddział II SGWP, I.303.4.3715, Informacje od wywiadu brytyjskiego z 28 X $1938 \mathrm{r}$. 
pancernych w III Rzeszy znalazł żywy oddźwięk również w wymianie informacji na ten temat pomiędzy służbami wywiadowczymi obu państw.

3 XI 1938 r. Brytyjczycy zwrócili się do strony polskiej z pytaniem, czy utworzony został XIX Korpus. Jeśli tak, to gdzie znajdowało się jego miejsce postoju i jaki był skład jednostek ${ }^{23}$. W odpowiedzi poinformowano centralę SIS, iż „istnienia XIX korpusu nie stwierdziliśmy dotychczas”. Wywiad brytyjski prosił również o wiadomości na temat 4 Dywizji Pancernej, o ile została ona sformowana ${ }^{24}$.

Pod koniec stycznia 1939 r. „dwójka” przekazała Brytyjczykom informacje dotyczące zasad walki wojsk pancernych oraz ich współdziałania z piechota. Napisano, że w kulminacyjnym punkcie bitwy niemieccy taktycy planuja pójść w kierunku użycia mas czołgów na waskim froncie i w głębokim ugrupowaniu. Zauważono, iż tworząc dyspozycyjne jednostki i związki czołgów w ramach korpusów, dążyli do uniknięcia ich rozproszenia i rozdzielenia. Unikali wiązania dywizji pancernych z ruchami piechoty, aby nie spowalniać tych pierwszych jednostek. Polski wywiad wojskowy przekazał Brytyjczykom także dane techniczne niemieckich czołgów.

Ważną rolę w wymianie informacji wywiadowczych odegrały ataszaty wojskowe obu państw. Oficjalnym przedstawicielem WP w Londynie był od 1 IX 1937 r. ppłk Bogdan Kwieciński, który wcześniej przebywał na placówce w Pradze ${ }^{25}$. Reaktywowanie po prawie dziewięciu latach ataszatu w stolicy Zjednoczonego Królestwa wynikało z sytuacji polityczno-wojskowej w Europie oraz silnej pozycji Wielkiej Brytanii na arenie międzynarodowej. Brytyjskim attaché militaire w Warszawie był w latach 1938-1939 ppłk Edward Sword. Zastapił on na tym stanowisku mjr. Johna Godfreya ${ }^{26}$. Rola ataszatów wojskowych obu państw znacznie wzrosła po podpisaniu 6 IV 1939 r. porozumienia zobowiązującego II Rzeczpospolitą i Wielką Brytanię do wzajemnej pomocy w razie agresji III Rzeszy. Poza wykonywaniem standardowych prac doszły wówczas nowe zadania, jak przygotowanie dwustronnych konferencji sztabowych czy też koordynacja współpracy wojskowej, a także wywiadowczej27.

${ }^{23}$ Ibidem, Informacje od wywiadu brytyjskiego z 3 XI 1938 r.

${ }^{24}$ Ibidem.

${ }^{25}$ P. Kołakowski, Między Warszawa a Praga..., passim.

${ }^{26}$ E.R. Sword, The Diary and Despatches of a Military Attaché in Warsaw, 1938-1939, London 2001, s. 21.

${ }^{27}$ R. Majzner, Attachaty wojskowe Drugiej Rzeczypospolitej 1919-1945. Strukturalno-organizacyjne aspekty funkcjonowania, Częstochowa 2014, s. 355. Rozszerzenie zadań ataszatu w Londynie oraz niebezpieczeństwo wybuchu wojny spowodowało wzmocnienie kadrowe tej placówki. W sierpniu 1939 r. jej obsadę personalną stanowili: ppłk Kwieciński (attaché wojskowy i lotniczy), mjr Stefan Dobrowolski (pomocnik), ppor. rez. Jerzy Konczyński (oficer przydzielony), kmdr ppor. Tadeusz Stoklasa (attaché morski) i kmdr ppor. Stanisław Lasocki (pomocnik). Ataszat mieścił się w budynku Ambasady RP przy Portland Place 47. 
W marcu 1939 r. Ministerstwo Wojny w Londynie przekazało ppłk. Kwiecińskiemu wiadomości o ruchach wojsk niemieckich i ich koncentracji do zajęcia Czechosłowacji. Wywiad brytyjski stwierdził, iż najprawdopodobniej postawione zostały na stopie wojennej jednostki VI Korpusu (Münster) i IX Korpusu (Kassel) oraz 1 Dywizja Lekka (Wuppertal) ${ }^{28}$. Zaobserwowano obsadzenie fortyfikacji wzdłuż Renu i w Zagłębiu Sary, a także intensywne prace nad umocnieniami na pograniczu wschodnim III Rzeszy, gdzie według poufnej wiadomości zatrudnionych było ok. 140 tys. ludzi. Z doniesień SIS wynikało, iż do 14 marca, czyli na dzień przed wkroczeniem do ČSR, Niemcy zgrupowali następujące siły: na Śląsku - 4 dywizje piechoty $(3,8,18,28)$, dywizję piechoty zmotoryzowanej (2), 2 dywizje pancerne $(3,5)$ i dywizję lekka (3); w Austrii - 2 dywizje piechoty $(44,45), 2$ dywizje pancerne $(2,4)$, lekką dywizję (4) i 2 dywizje górskie $(2,3)$, a także na północno-zachodniej granicy Czechosłowacji - 4 dywizje piechoty $(4,14,24,46)$, dywizję pancerna (1) oraz dywizję piechoty zmotoryzowanej (20). W sumie skoncentrowano ok. 21 wielkich jednostek, które wzięły udział w operacji zajęcia Czech i Moraw oraz części Słowacji29.

Z kolei 22 III 1939 r. attaché wojskowy w Londynie przekazał droga telegraficzną ważną wiadomość do centrali wywiadu wojskowego w Warszawie o niemieckich przygotowaniach do zajęcia Kłajpedy. Potwierdziło to doniesienia Oddziału II. Podpułkownik Kwieciński informował o postawieniu garnizonów II Korpusu (Szczecin) w stan pogotowia. Następnego dnia wieczorem otrzymano od Brytyjczyków wiadomość, że część zarządzeń dotyczących ogłoszenia pogotowia w garnizonach na obszarze całych Niemiec została złagodzona ${ }^{30}$. Naświetlając sytuację polityczna, polski attaché wojskowy 23 marca pisał: „W stosunku do Polski zmieniły się nastroje bardzo i sa w chwili obecnej nadzwyczaj przychylne. Sytuacja nasza i sposób rozgrywania sprawy z Niemcami znajduje tu duże zrozumienie. Panuje tu niewątpliwe przekonanie, że zaatakowani będziemy się bili, a wartość polskiej siły zbrojnej oceniana jest bardzo dodatnio". W jego ocenie największe zainteresowanie czynników brytyjskich wzbudzała sprawa Gdańska ${ }^{31}$.

26 marca ppłk Kwieciński poinformował Oddział II o powrocie części jednostek biorących udział w zajęciu Czechosłowacji do swoich garnizonów ${ }^{32}$. Dwa dni później polski attaché, analizując sytuację polityczna, stwierdził w raporcie:

\footnotetext{
${ }^{28}$ Według doniesień wywiadu brytyjskiego pogotowie zostało ogłoszone w garnizonie królewieckim. Ponadto nastapił ruch wojsk w kierunku granicy polskiej w Prusach Wschodnich.

${ }^{29}$ CAW, Oddział II SGWP, I.303.4.3872, Informacje otrzymane z brytyjskiego Ministerstwa Wojny 20 i 22 III 1939 r.

${ }^{30}$ Ibidem, Raport attaché wojskowego ppłk. Kwiecińskiego z 28 III 1939 r.; ibidem, Informacje otrzymane z brytyjskiego Ministerstwa Wojny 20 i 22 III 1939 r.

${ }^{31}$ Ibidem, Raport attaché wojskowego ppłk. Kwiecińskiego z 23 III 1939 r.

${ }^{32}$ Ibidem, I.303.3866, Meldunek sytuacyjny nr 15 z 26 III 1939 r. (27 III 1939 r.). Attaché polski otrzymał te informacje z Ministerstwa Wojny 25 marca.
} 
Przychylny nastrój dla Polski i przekonanie o tym, że jesteśmy zdecydowani przeciwstawić się wszelkim próbom agresji nadal się utrzymuje a nawet wzmaga [...]. Nie wykluczam, że nastrój ten jest naumyślnie wytwarzany, nie mogę naturalnie ocenić w jakim stopniu jest świadomie robiony by wpędzić nas w konflikt z Niemcami. Nie ulega wątpliwości, że pewne strefy chętnie widziałyby taki konflikt ${ }^{33}$.

Należy przyznać, iż ocena ppłk. Kwiecińskiego była trafna i świadczyła o nieufności wobec polityki Londynu.

Polski wywiad wojskowy starał się na bieżąco weryfikować wiadomości otrzymywane od SIS, podobnie jak czyniono to w odniesieniu do służb wywiadowczych innych państw. Według informacji wywiadu brytyjskiego pod koniec marca w Czechach i na Morawach znajdowały się następujące jednostki: 2, 3, 5 i prawdopodobnie 4 Dywizje Pancerne; 29 oraz części 2 i 20 Dywizji Piechoty (zmotoryzowanych) 3, 4 i najprawdopodobniej 2 Dywizje Lekkie; 2 i 3 Dywizje Górskie; 3, 4, 7, 8, 24, 44, 45 i 46 Dywizje Piechoty oraz prawdopodobnie 9 i 31 Dywizje Piechoty ${ }^{34}$. Do miejsc swojego stacjonowania powróciły: 1 Dywizja Pancerna, 18 Dywizja Piechoty, 28 Dywizja Piechoty i część 2 Dywizji Piechoty zmotoryzowanej. Z doniesień wywiadu brytyjskiego wynikało, iż 28 marca wszystkie wielkie jednostki w zachodnich Niemczech znajdowały się ,jeszcze” w garnizonach, jednak podwyższone zostały ich stany liczebne do wojennych ${ }^{35}$.

Ciekawe, iż decyzję rządu Jego Królewskiej Mości o gwarancjach dla Polski poprzedziły informacje wywiadu o zbliżającej się agresji na II Rzeczpospolitą. Doniesienia te pojawiły się nad Tamizą 28 III 1939 r. Następnego dnia potwierdził je Ian Alvin - korespondent „News Chronicle” w Berlinie. Zauważmy, że również wywiad francuski, a także polska „dwójka” pod koniec marca brały pod uwagę możliwość zajęcia Gdańska (co miało rzekomo nastapić 1 kwietnia) lub wręcz zaatakowania II Rzeczypospolitej. Informacje te okazały się jednak nieprawdziwe ${ }^{36}$.

Udzielenie Polsce gwarancji 31 III 1939 r. przez premiera Arthura Neville'a Chamberlaina, które 6 kwietnia w trakcie wizyty ministra spraw zagranicznych Józefa Becka w Londynie zostały zastapione zobowiazaniem o wzajemnej pomocy w razie ataku Niemiec, przyczyniło się do zacieśnienia

${ }^{33}$ Cyt. za: P. Kołakowski, Czas próby. Polski wywiad wojskowy wobec groźby wybuchu wojny w 1939 roku, Warszawa 2012, s. 276-277.

${ }^{34} \mathrm{Z}$ informacji uzyskanych przez „dwójkę" wynikało jednak, iż z 3, 7 i 8 Dywizji Piechoty na terenie Protektoratu Czech i Moraw znajdowały się tylko poszczególne oddziały. Nie było tam całych jednostek.

${ }^{35}$ Odnotujmy też, że według wiadomości przekazanych przez Brytyjczyków 1 Dywizja Lekka znajdowała się 26 marca w swoich garnizonach, podobnie jak „sztab i jednostki” 13 Dywizji Piechoty (Magdeburg). Żołnierze z 6 Dywizji Piechoty (Bielefeld) otrzymali 14-dniowe urlopy.

${ }^{36}$ A. Pepłoński, A. Suchcitz, J. Tebinka, Wspótpraca wywiadowcza $w$ drugiej połowie lat trzydziestych XX w., w: Polsko-brytyjska wspótpraca wywiadowcza..., t. I, s. 181; P. Kołakowski, Czas próby..., s. 134-135. 
więzi pomiędzy wywiadami obu państw. Trzeba pamiętać, iż nie nastapiło to od razu. Wpływ na taka sytuację miał obopólny brak zaufania, a także niedysponowanie przez wywiad brytyjski odpowiednia wiedzą o potencjale militarnym III Rzeszy. Stanowiło to efekt nieprzygotowania aparatu wywiadowczego tego państwa do działalności w okresie napięcia wojennego, a także konfliktu zbrojnego ${ }^{37}$. Stopniowo współpraca zaczęła się jednak rozwijać na trzech płaszczyznach: informacyjnej, dywersyjnej i radiowywiadowczej ${ }^{38}$. Major Szumowski - kierownik Referatu „Zachód” - w swojej relacji stwierdził, iż „informacje brytyjskie były nader skape i ogólnikowe, ogólnie biorąc o małej wartości”. Nie należy też zapominać, że Brytyjczycy niechętnie wymieniali wiadomości, zwłaszcza te o znaczeniu strategicznym. Nie będzie jednak zbytnia przesada stwierdzenie, że SIS nie miał w tym czasie zbyt wiele do zaoferowania Oddziałowi II. Decydujacy wpływ na zacieśnienie współpracy wywierały względy polityczne i ogólnostrategiczne spowodowane rozwojem sytuacji w Europie ${ }^{39}$.

Na początku kwietnia 1939 r. Brytyjczycy poinformowali Oddział II, iż doniesienia o koncentracji wojska niemieckiego w rejonie Würtemberg w pobliżu Jeziora Bodeńskiego i południowej Bawarii nie potwierdziły się ${ }^{40}$. Z kolei w maju przekazali wiadomość z marca, pochodząca z pewnego źródła, o stwierdzeniu w Wiedniu oddziału pancernego wchodzacego w skład 4 Dywizji Lekkiej ${ }^{41}$, a w czerwcu równie „pewną” jakoby w 76 Pułku Artylerii oraz zmotoryzowanym 4 Pułku Kawalerii z 1 Dywizji Lekkiej zostały wstrzymane

${ }^{37}$ Braki w przygotowaniu wywiadu brytyjskiego do wojny wynikały w dużej mierze z ograniczeń finansowych. Na cięcia w budżecie skarżył się długoletni szef SIS adm. Hugh Sinclair. Stał on na czele tej służby w latach 1923-1939 (po nim kierownictwo obją w listopadzie 1939 r. płk Menzies). Zła była też organizacja, jak również metody pracy wywiadu brytyjskiego. Szerzej zob. G. Bennett, Brytyjski wywiad w okresie II wojny światowej, w: Polsko-brytyjska wspótpraca wywiadowcza..., t. I, s. 138-140.

38 WBBH, MiD, I/3/60, Ppłk L. Sadowski, Oddział II Sztabu Głównego. Rezultaty pracy pokojowej i udział w przygotowaniach do wojny, s. 103; A. Pepłoński, A. Suchcitz, J. Tebinka, op. cit., s. 181.

${ }^{39}$ WBBH, MiD, I/3/94, Sprawozdanie mjr dypl. Tadeusza Sumowskiego..., s. 11. Zauważmy, iż wywiad brytyjski współpracował bardzo ściśle na tajnym froncie z Francuzami. Od nich otrzymywał wiele informacji o niemieckich planach, a także potencjale militarnym III Rzeszy. Trzeba też wspomnieć o współpracy SIS z wywiadem czechosłowackim, a po likwidacji tego państwa w marcu 1939 r. z grupą wywiadowczą płk. Františka Moravca. To właśnie przy pomocy SIS wysokiej rangi oficerowie czeskiej „dwójki” przed zajęciem przez Niemców Pragi ewakuowali się do Londynu. Grupa Moravca dysponowała bardzo cennym agentem, którym był oficer Abwehry - Paul Thümmel „A-54”. Do aresztowania w październiku 1941 r. dostarczał on ważnych informacji o zamiarach Hitlera, a także niemieckich siłach zbrojnych. Uprzedził m.in. o planowanym wkroczeniu Wehrmachtu do Czechosłowacji oraz ataku na Polskę. J. Ciechanowski, op. cit., s. 146, 153-155; P. Kołakowski; Między Warszawa a Praga..., s. 598, 613-614, 627.

${ }^{40}$ CAW, Oddział II SGWP, I.303.4.3900, Dziennik wiadomości nr 23 z 3 IV 1939 r.

${ }^{41}$ Ibidem, I.303.4.3899, Sprawozdanie Informacyjne nr 70 z 20 V 1939 r. (21 V 1939 r.). 
od 26 tego miesiąca wszystkie urlopy. Tego samego dnia pułk artylerii miał wyruszyć na manewry w okolice Berlina. Jego stany zostały podwyższone przez powołanie rezerwistów ${ }^{42}$. Ta ostatnia wiadomość stanowiła częściowe potwierdzenie wcześniejszych doniesień. Wyraźnie widać, iż przekazywane przez wywiad brytyjski informacje nie wnosiły istotnych zmian do oceny położenia polityczno-wojskowego II Rzeczypospolitej.

20 III 1939 r. ppłk Sword depeszą szyfrową meldował do Londynu, że płk Józef Englicht, który pełnił funkcję pierwszego zastępcy szefa wywiadu, poinformował go poprzedniego dnia o wycofaniu z Gdańska części oddziałów SA, jakie przybyły tam między 9 a 11 tego miesiąca. Ich liczebność została zredukowana do ok. 12 tys. ludzi. Englicht wspomniał też, iż Niemcy zrezygnowali w najbliższej przyszłości z planu wysłania z wizytą do Gdańska okrętu wojennego ${ }^{43}$.

Wiosną 1939 r. SIS zwróciła się do polskiej „dwójki” z prośbą o udzielenie odpowiedzi na szereg pytań odnośnie do niemieckich sił powietrznych. Chodziło przede wszystkim o podanie danych dyslokacyjnych niektórych dywizjonów myśliwskich, bombowych oraz rozpoznawczych. Poszukiwano również informacji o ich nowej numeracji z powodu wprowadzenia przez Niemców zmian, a także o typach samolotów, w jakie były wyposażone. Polski wywiad wojskowy udzielił odpowiedzi na większość pytań Brytyjczyków, co dowodzi dobrego rozpoznania Luftwaffe u progu II wojny światowej. Wspomnieć należy, iż SIS otrzymywał też wiele wartościowych informacji na temat jednostek spadochronowych. Dotyczyły one m.in. ich organizacji, wyszkolenia i wyekwipowania ${ }^{44}$. Nie jesteśmy $\mathrm{w}$ stanie określić, $\mathrm{w}$ jakim stopniu wiadomości te zostały wykorzystane przez Brytyjczyków na własne potrzeby.

Pozytywny wpływ na współpracę służb wywiadowczych obu państw miały spotkania przedstawicieli sił zbrojnych Polski oraz Zjednoczonego Królestwa. W ostatnim tygodniu maja 1939 r. rozmowy sztabowe w Warszawie prowadził brygadier (odpowiednik w WP generała brygady) Emilius Clayton, który był pierwszym attaché militaire Wielkiej Brytanii w II Rzeczypospolitej. Spotkania z czołowymi oficerami sztabowymi WP miały charakter informacyjny. Brytyjczycy chcieli zorientować się przede wszystkim w możliwościach obronnych państwa polskiego, natomiast Polacy dążyli do wyjaśnienia, jakiej pomocy moga oczekiwać od Londynu w razie ataku niemieckiego. Rzeczą znamienną było, iż delegacja brytyjska, znajdując się już w Warszawie, otrzymała polecenie zniszczenia dokumentów, które stanowiły opis brytyjsko-francuskich rozmów międzysztabowych z początku maja 1939 r. W ich trakcie dowiedziano się, że armia francuska nie podejmie działań ofensywnych na froncie zachodnim

\footnotetext{
${ }^{42}$ Ibidem, I.303.4.3897, Sprawozdanie Informacyjne nr 104 z 23 VI 1939 r. (24 VI 1939 r.).

${ }^{43}$ E.R. Sword, op. cit., s. 134.

${ }^{44} \mathrm{Z}$ ustaleń Aleksandra Woźnego wynika, iż wywiad brytyjski rewanżował się Oddziałowi II informacjami o jednostkach specjalnych. Zob. idem, op. cit., s. 99-100.
} 
wspomagających Wojsko Polskie walczace z Wehrmachtem. Stanowiło to spore zaskoczenie dla Brytyjczyków, bowiem przekreśliło plany wojny na dwóch frontach, której tak bardzo obawiali się Niemcy ${ }^{45}$. O ustaleniach tych nie poinformowano strony polskiej, łudząc ją obietnicami aktywnej pomocy militarnej.

Podobne znaczenie miała również wizyta w Polsce Inspektora Zamorskich Sił Zbrojnych gen. Edmunda Ironside'a w dniach od 17 do 21 VII 1939 r. Odnotujmy, iż znał on język polski i uważany był za przyjaźnie nastawionego do Polski i Polaków. Główny cel przyjazdu Ironside’a stanowiło zorientowanie się w woli oporu II Rzeczypospolitej. Brytyjski generał zapewnił swoich rozmówców, że Wielka Brytania udzieli natychmiastowego wsparcia państwu polskiemu. Obiecał też pomoc materialną oraz finansową na zakup uzbrojenia, co przyjęto z zadowoleniem ${ }^{46}$.

17 V 1939 r. do Warszawy droga lotniczą przybył mjr/ppłk Colin McVean Gubbins, specjalista od techniki wojny nieregularnej. W latach 1943-1946 stał na czele powstałego w lipcu 1940 r. Zarządu Operacji Specjalnych (Special Operations Executive - SOE), który miał za zadanie - jak to barwnie określił Winston Churchill - „podpalić Europe”. SOE prowadził intensywne działania dywersyjno-sabotażowe, zdobywał informacje wywiadowcze, a także wspomagał ruch oporu. Gubbins był znany z dużej sympatii do Polaków, co wywoływało ironiczne komentarze niektórych jego współpracowników i przełożonych ${ }^{47}$. Jego majowa wizyta w 1939 r. (odwiedził również państwa bałtyckie i Rumunię) miała związek z planami działań dywersyjnych i sabotażowych w przypadku, gdyby doszło do wojny z Niemcami hitlerowskimi. W stolicy Polski rozmawiał m.in. z przedstawicielem SIS mjr. Shelleyem ${ }^{48}$.

W obliczu narastającego zagrożenia wojennego w lipcu 1939 r. ppłk Gubbins przyjechał ponownie do Warszawy z propozycją nawiązania współpracy w zakresie prowadzenia propagandy na Niemcy. Celem tej akcji byłoby niedopuszczenie do wybuchu wojny oraz ewentualne odsunięcie Adolfa Hitlera od władzy. Propozycje Brytyjczyków spotkały się z dużym zainteresowaniem kierownictwa Oddziału II Sztabu Głównego WP, które wyraziło zgodę na taka współpracę. Gubbins nawiązał kontakt z ppłk. Stanisławem Gano, stojącym na czele Samodzielnego Referatu Technicznego, jak również z ppłk. Józefem Skrzydlewskim, kierującym Wydziałem III, odpowiedzialnym za planowanie wywiadu, dywersji i propagandy wojennej ${ }^{49}$. Ten ostatni oficer polskiego wywiadu wojskowego tak opisał swoje kontakty ze stroną brytyjską:

${ }^{45}$ P. Kołakowski, Czas próby..., s. 49-50; A. Pepłoński, A. Suchcitz, J. Tebinka, op. cit., s. 181-182.

${ }^{46}$ Zob. A. Suchcitz, Wrażenia generała Ironside'a $z$ wizyt $w$ Polsce $w$ latach $1925 i$ 1939, „Mars” 1993, nr 1, s. 60-64; P. Kołakowski, Czas próby..., s. 50-51.

${ }^{47}$ E. Maresch, Zarzad Operacji Specjalnych, w: Polsko-brytyjska wspótpraca wywiadowcza..., t. I, s. $162-163$.

${ }^{48}$ E.R. Sword, op. cit., s. 41-42.

${ }^{49}$ A. Pepłoński, A. Suchcitz, J. Tebinka, op. cit., s. 183. 
W ostatnich kilku tygodniach przed wojną zawiązała się żywsza współpraca z centrala angielskiej propagandy wojenno-dywersyjnej. Odbyłem kolejno w Warszawie konferencję z dwoma wysłannikami sztabu angielskiego, z którymi omówiłem środki i metody propagandy dywersyjnej i ustaliłem formy współpracy przy wykorzystaniu dróg penetracji na teren Rzeszy Niemieckiej. Ponadto Anglicy zaproponowali nam wykorzystanie specjalnych środków do kolportażu bibuły propagandowej. Techniczne wykorzystanie tych środków zostało szczegółowo omówione ${ }^{50}$.

Oddział II, co zostało przedstawione Brytyjczykom przez ppłk. Skrzydlewskiego, obawiał się jedynie, by akcja ta nie wywołała zmasowanych odwetów działań propagandy ze strony niemieckiej, dysponującej zdecydowanie większymi możliwościami w tym względzie. W tym czasie „dwójka” zabiegała o pozyskanie w Wielkiej Brytanii sprzętu technicznego. Chodziło przede wszystkim o radiostacje średniego zasięgu ${ }^{51}$. Działania w zakresie wojennej propagandy dywersyjnej nie wyszły de facto poza prace teoretyczne. Zdecydował o tym brak ludzi oraz przede wszystkim czasu, jaki pozostał do wybuchu wojny ${ }^{52}$.

O zacieśniającej się współpracy wywiadowczej polsko-brytyjskiej przed wybuchem wojny świadczyło mianowanie z dniem 1 VIII $1939 \mathrm{r}$. mjr. Stefana Dobrowolskiego pomocnikiem attaché wojskowego w Londynie. Miał on de facto pełnić rolę stałego łącznika pomiędzy Oddziałem II Sztabu Głównego WP a wywiadem Zjednoczonego Królestwa. Do jego zadań należało przede wszystkim odbieranie informacji wywiadowczych $\mathrm{z}$ centrali SIS.

W ostatnich tygodniach przed agresja Niemiec hitlerowskich na Polskę Oddział II na bieżąco dostarczał zarówno attaché wojskowemu, jak i przedstawicielom brytyjskiego wywiadu w Warszawie informacje naświetlające aktualne położenie militarne. Przekazywano głównie dane odnośnie do przygotowań mobilizacyjnych, ruchu i dyslokacji wielkich jednostek oraz odbywającej się koncentracji wojsk przy granicy polskiej, a także o sytuacji wojskowo-politycznej w Rzeszy, Protektoracie Czech i Moraw oraz Słowacji i w Gdańsku. Informowano również o pracach fortyfikacyjnych. Ponadto sporadycznie dostarczano wiadomości o ruchu okrętów wojskowych oraz transportach niemieckich na Bałtyku. Zestawieniami codziennych komunikatów informacyjnych dla sztabu brytyjskiego (jak również francuskiego) zajmował się mjr Jan Leśniak kierujący Samodzielnym Referatem Sytuacyjnym „Niemcy”. On również z polecenia pierwszego zastępcy szefa Oddziału II, płk. Englichta przekazywał ustnie wiadomości attaché wojskowym państw sojuszniczych i zaprzyjaźnionych o niemieckich przygotowaniach

\footnotetext{
${ }^{50}$ Archiwum Instytutu Polskiego i Muzeum im. gen. Sikorskiego (dalej: AIPMS), B.I.6i, Relacja ppłk. Józefa Skrzydlewskiego z 24 XI 1939 r.

51 A. Pepłoński, A. Suchcitz, J. Tebinka, op. cit., s. 183.

52 Jedynym efektem tych prac było najprawdopodobniej wydrukowanie i rozesłanie ulotek na terenie Wolnego Miasta Gdańska. Zob. ibidem.
} 
do wojny ${ }^{53}$. Z rezydentem wywiadu brytyjskiego ppłk. Shelleyem współpracował Referat „Zachód” 54 .

20 VII 1939 r. ppłk Sword przesłał do War Office depesze z informacjami, jakie otrzymał poprzedniego dnia od szefa Oddziału II płk. Smoleńskiego. Według udostępnionych Brytyjczykom wiadomości siły niemieckie w Gdańsku stanowiły równowartość dywizji piechoty. Ostatnie doniesienia wywiadu polskiego mówiły o wstrzymaniu przemytu uzbrojenia, amunicji oraz wyposażenia wojskowego na obszar Wolnego Miasta. Smoleński zwrócił uwage na zwiększenie liczebności wojsk niemieckich w pobliżu granicy polskiej o ok. 5 dywizji. Jego zdaniem wszystko wskazywało na to, iż nie był to koniec napływu wielkich jednostek ${ }^{55}$.

$\mathrm{Z}$ analiz Oddziału II przekazanych Brytyjczykom wynikało, że przy założeniu, iż powszechna mobilizacja w Niemczech została rozpoczęta 26 sierpnia, Wehrmacht zakończy koncentrację jednostek do ataku na Polskę ok. 3 września. Meldunki „dwójki” wskazywały na całkowita dezorganizację armii słowackiej, co nie odpowiadało prawdzie. Sword został poinformowany również o zmianach, jakie zaszły od 27 do 29 sierpnia w rozpoznaniu jednostek niemieckich koncentrujacych się blisko granicy polskiej. W zamian do Oddziału II docierały wiadomości o niemieckich przygotowaniach do wojny, jakimi dysponowali Brytyjczycy. 25 sierpnia poinformowali oni, iż następnego dnia III Rzesza zakończy przygotowania do agresji na Polskę. SIS najprawdopodobniej informację tę uzyskał od grupy wywiadowczej płk. Moravca $^{56}$. 30 sierpnia z brytyjskiej Misji Wojskowej w Polsce ${ }^{57}$, na której czele stał gen. Adrian Carton de Wiart, przekazano treść meldunku otrzymanego z Londynu. Zawarta w nim była informacja o poważnych rozbieżnościach, do jakich miało dojść między Hitlerem a niektórymi dowódcami niemieckimi. Führer rzekomo żądał uderzenia na Pomorze zamiast planowanego ataku

${ }^{53}$ AIPMS, A.II.27/54, Sprawozdanie mjr Jana Leśniaka z 9 I 1940 r. (załącznik do zeszytu ewidencyjnego). W Oddziale II za kontakty z oficjalnymi przedstawicielami sił zbrojnych państw obcych odpowiadał Samodzielny Referat Ogólny, którym kierował mjr Antoni Ślósarczyk.

${ }^{54}$ Ibidem, B.I.6f, Sprawozdanie kpt. Mieczysława Jaworskiego z 17 V 1940.

${ }^{55}$ E.R. Sword, op. cit., s. 140.

56 P. Kołakowski, Między Warszawa a Praga..., s. 627.

${ }^{57}$ Brytyjska Misja Wojskowa w Polsce została powołana 24 VIII 1939 r. W jej skład weszli również oficerowi i pracownicy ataszatu, a także SIS pracujący w Urzędzie Kontroli Paszportowej Ambasady Brytyjskiej w Warszawie na czele z rezydentem wywiadu ppłk. Shelleyem. Już po wybuchu wojny dołączył do nich ppłk Gubbins wraz z grupą specjalistów w zakresie sabotażu. Jego zadaniem było przede wszystkim ustalenie założeń współdziałania ze strona polską oraz przedstawienie rezultatów rozpoznania wywiadowczego, przekazania map i komunikatów informacyjnych, a także wskazanie szlaków komunikacyjnych, które mogły być wykorzystane do zaopatrzenia WP. Dopiero na początku września 1939 r. do Londynu wyjechała polska misja wojskowa. Na jej czele stał gen. Mieczysław Norwid-Neugebauer. A. Pepłoński, A. Suchcitz, J. Tebinka, op. cit., s. 184. 
z północy i południa. Jeden z wyższych oficerów miał z tego powodu podać się do dymisji. Informacje brytyjskie mówiły też o załamaniu nerwowym Hitlera, który znalazł się pod opieką specjalistów ${ }^{58}$.

Ostatniego dnia pokoju ppłk Sword poinformował depeszą szyfrową War Office, iż według kalkulacji Oddziału II Sztabu Głównego WP Wehrmacht skoncentrował na granicy polskiej od 42 do 54 dywizji. Przekazano mu również informację o zarejestrowaniu w ciagu ostatnich 24 godzin trzech incydentów granicznych. Powiadomiono też ppłk. Sworda, iż mobilizacja WP przebiegała zgodnie z planem z wyjątkiem kilku incydentów ${ }^{59}$.

Służby informacyjne Wielkiej Brytanii z pewnością nie były idealnym partnerem Oddziału II SGWP w dwudziestoleciu międzywojennym. Znacznie lepiej układała się współpraca z wywiadem francuskim czy też do pewnego momentu czechosłowackim, a także innymi służbami wywiadowczymi. Wybuch wojny - klęska najpierw Polski, a następnie Francji - otworzyły nowy etap współpracy polsko-brytyjskiej na tajnym froncie. Wkład polskiego wywiadu wojskowego w zwycięstwo nad III Rzeszą okazał się niebagatelny.

\section{Streszczenie}

Do pierwszych polsko-brytyjskich kontaktów wywiadowczych doszło w okresie wojny Polski z Rosją bolszewicka. Były one systematycznie rozszerzane i z czasem objęły zarówno wymianę informacji o Związku Sowieckim, jak i o Niemczech. Początkowo obie strony do kontaktów tych podchodziły z rezerwa. Dopiero w drugiej połowie lat trzydziestych polsko-brytyjska współpraca wywiadowcza stała się bardziej aktywna, jednak nie osiagnęła poziomu współdziałania z sojuszniczymi służbami specjalnymi Francji. Efekty zaczęło przynosić porozumienie zawarte między przedstawicielami Secret Intelligence Service (SIS) a Oddziałem II SGWP. Brytyjczycy zabiegali u strony polskiej przede wszystkim o informacje dotyczące potencjału militarnego III Rzeszy i ZSRS. W kręgu ich zainteresowań znalazły się także nowe rodzaje uzbrojenia, rozbudowa sił powietrznych oraz broni pancernej. Polski wywiad wojskowy starał się udzielać jak najszybciej odpowiedzi na te pytania. Przełom w polsko-brytyjskiej współpracy wywiadowczej nastapił jednak dopiero w kwietniu 1939 r. po udzieleniu wzajemnych gwarancji przez II Rzeczpospolitą i Zjednoczone Królestwo. Od tego momentu współpraca zaczęła rozwijać się na trzech płaszczyznach: informacyjnej, sabotażowo-dywersyjnej i radiowywiadowczej. Ważną rolę w wymianie informacji między centralami wywiadowczymi obu państw odgrywała placówka wywiadu brytyjskiego w Polsce, kierowana przez mjr./ppłk. Johna P. Shelleya, a także attaché wojskowych - brytyjskiego w Warszawie i polskiego w Londynie. U progu II wojny światowej obie strony informowały się o ruchach jednostek Wehrmachtu oraz o przygotowaniach niemieckich do agresji na Polskę.

\footnotetext{
${ }^{58}$ AIPMS, A.II.27/34, Informacje odebrane od brytyjskiej Misji Wojskowej z 30 VIII 1939 r.; P. Kołakowski, Czas próby..., s. 279.

${ }^{59}$ E.R. Sword, op. cit., s. 150.
} 


\section{Cooperation of the Polish military intelligence with the British Secret Intelligence Service in the second half of the 1930s}

First Polis-British intelligence contacts took place during the war between Poland and the Bolshevik Russia. They were systematically intensified and in time they included both the exchange of information on the Soviet Union and on Germany. Initially both countries treated those contacts with reserve, and it was not until the second half of the 1930s that they became more effective, but they did never reach the intensity of cooperation with the French special services. There were some effects of the agreement between the British Secret Intelligence Service (SIS) and the Second Department of the Polish General Staff. The British were mainly interested in the information on military potential of the Third Reich and the USSR, but also in new types of weapons, the development of air forces and armoured troops. The Polish military intelligence tries to answer all those questions as soon as possible. A breakthrough in the cooperation took place in April 1939, after the United Kingdom and Poland formalised their mutual military assistance in the event of aggression of the Third Reich. From that moment on, the cooperation developed in three main sectors: informative, sabotage and subversive, and radio intelligence ones. An important part in the exchange of information between the two countries was played by the British intelligence post in Poland, headed by Major John P. Shelley, and also military attachés - Britihs in Warsaw and Polish in London. At the outbreak of World War II both states exchanged their information on the deployment of the Wehrmacht units and German preparations for aggression of Poland.

\section{Bibliografia}

Bennett G., Brytyjski wywiad w okresie II wojny światowej, w: Polsko-brytyjska wspótpraca wywiadowcza podczas II wojny światowej, t. I: Ustalenia Polsko-Brytyjskiej Komisji Historycznej, red. T. Dubicki, D. Nałęcz, T. Stirling, Warszawa 2004, s. 137-142.

Ciechanowski J., Brytyjskie stużby specjalne, w: Polsko-brytyjska wspótpraca wywiadowcza podczas II wojny światowej, t. I: Ustalenia Polsko-Brytyjskiej Komisji Historycznej, red. T. Dubicki, D. Nałęcz, T. Stirling, Warszawa 2004, s. 143-159.

Ćwięk H., W tajnej stużbie II Rzeczypospolitej. Wywiad polski wobec Niemiec 1918-1939, Częstochowa 2009.

Gondek L., Wywiad polski w III Rzeszy 1933-1939. Zarys struktury, taktyki i efektów obronnego działania, Warszawa 1982.

Kołakowski P., Czas próby. Polski wywiad wojskowy wobec groźby wybuchu wojny w 1939 roku, Warszawa 2012.

Kołakowski P., Między Warszawa a Praga. Polsko-czechosłowackie stosunki wojskowo-polityczne 1918-1939, Warszawa 2007.

Majzner R., Attachaty wojskowe Drugiej Rzeczypospolitej 1919-1945. Strukturalno-organizacyjne aspekty funkcjonowania, Częstochowa 2014.

Maresch E., Zarzqd Operacji Specjalnych, w: Polsko-brytyjska wspótpraca wywiadowcza podczas II wojny światowej, t. I: Ustalenia Polsko-Brytyjskiej Komisji Historycznej, red. T. Dubicki, D. Nałęcz, T. Stirling, Warszawa 2004, s. 160-166.

Nowak-Kiełbikowa M., Polska - Wielka Brytania w dobie zabiegów o zbiorowe bezpieczeństwo w Europie 1923-1937, Warszawa 1989.

Nurek M., Polska w polityce Wielkiej Brytanii w latach 1936-1941, Warszawa 1983.

Pepłoński A., Wywiad polski na ZSRR 1921-1939, Warszawa 1996.

Pepłoński A., Suchcitz A., Tebinka J., Wspótpraca wywiadowcza $w$ drugiej połowie lat trzydziestych XX w., w: Polsko-brytyjska wspótpraca wywiadowcza podczas II wojny 
światowej, t. I: Ustalenia Polsko-Brytyjskiej Komisji Historycznej, red. T. Dubicki, D. Nałęcz, T. Stirling, Warszawa 2004, s. 177-188.

Suchcitz A., Wrażenia generała Ironside’a $z$ wizyt $w$ Polsce $w$ latach 1925 i 1939, „Mars” 1993, nr 1 .

Sword E.R., The Diary and Despatches of a Military Attaché in Warsaw, 1938-1939, London 2001.

Woźny A., Niemieckie przygotowania do wojny z Polskq w ocenach polskich naczelnych władz wojskowych w latach 1933-1939, Warszawa 2000.

Zacharias M.J., Polityka Wielkiej Brytanii w przededniu drugiej wojny światowej, w: Droga $k u$ wojnie. Polityka europejska $i$ amerykańska $w$ przededniu drugiej wojny światowej, red. T. Kisielewski, Bydgoszcz 1999, s. 85-104.

Biogram: Piotr Kołakowski - prof. dr hab., historyk pierwszej połowy XX w., profesor zwyczajny w Akademii Pomorskiej w Słupsku, gdzie kieruje Zakładem Stosunków Międzynarodowych w Instytucie Historii i Politologii. Zajmuje się zagadnieniami związanymi z działalnością polskich i obcych służb specjalnych, a także stosunkami polityczno-wojskowymi w dwudziestoleciu międzywojennym. Autor i współautor 15 książek oraz licznych artykułów zamieszczonych w polskich i zagranicznych periodykach naukowych. E-mail: kolakowski.piotr@wp.pl. 